Amasya Ilahiyat Dergisi - Amasya Theology Journal

ISSN 2667-7326 | e-ISSN 2667-6710

Haziran / June 2021, 16: 395-419

\title{
Namazın Rükünlerinde Kadın ve Erkeklere Yönelik Farklı Hükümler
}

\author{
Fatiha BOZBAŞ \\ Dr. Öğr. Üyesi, Selçuk Üniversitesi, İslâmî İlimler Fakültesi, \\ F1kıh Anabilim Dalı \\ Assistant Professor, Selçuk University, Faculty of Islamic Studies, \\ Department of Fiqh \\ Konya, Turkey \\ fatiha.bozbas@selcuk.edu.tr \\ orcid.org/0000-0001-7775-3869
}

\section{Makale Bilgisi / Article Information}

Makale Türü / Article Types: Araştırma Makalesi / Research Article

Geliş Tarihi / Received: 30 Ocak / January 2021

Kabul Tarihi / Accepted: 15 Mart / March 2021

Yayın Tarihi / Published: 30 Haziran / June 2021

Yayın Sezonu / Pub. Date Season: Haziran / June

Sayı / Issue: 16 Sayfa / Pages: 395-419

Atıf / Cite as: Bozbaş, Fatiha. "Namazın Rükünlerinde Kadın ve Erkeklere Yönelik Farklı Hükümler [Different Provisions Regarding Women and Men in Ritulas of Prayer]". Amasya Ilahiyat Dergisi-Amasya Theology Journal 16 (June 2021): 395-419.

https://doi.org/10.18498/amailad.871129.

Intihal / Plagiarism: Bu makale, en az iki hakem tarafından incelendi ve intihal içermediği teyit edildi. / This article has been reviewed by at least two referees and scanned via a plagiarism software.

Copyright (C) Published by Amasya Üniversitesi, İlahiyat Fakültesi / Amasya University, Faculty of Theology, Amasya, 05100 Turkey. All rights reserved. https://dergipark.org.tr/amailad. 
396 | F. BOZBAŞ / Namazın Rükünlerinde Kadın ve Erkeklere Yönelik Farklı Hükümler

\section{Different Provisions Regarding Women and Men in Rituals of Prayer}

\section{Abstract}

When the judiciary in the classical figh literature is evaluated in a general framework, while there is no difference between men and women in terms of both the execution of the judiciary and the principles of the judiciary, there are different provisions for men and women for example; there is no religious duty of zakah for women in terms of religious cult, and there are other differences such as testimony in transactions and blood money in criminal law. Fundamentally there is no difference between men and women in the provisions of the prayer in terms of religious cult of figh. In the Nass, elaborate details regarding to the conditions and provisions of prayer are not defined in the verses of Quran, whereas Sunnah and practices of Prophet's companions regarding the conditions and provisions of the Salah constitutes the basis for the prayer. When we look at the narrations from the Prophet concerning the prayer, it is understood that there is no fundamental difference between men and women in the conditions and rituals of prayer, however there are narrations which particularly refer to women and includes the condition of Setr-i awrah (covering intimate parts of the body). Aside from the absence of any nass (written law) about women's prayers, except for the setr-i awret (covering intimate parts of the body), as it is narrated in the hadith that "Go back to your families. Teach them religious knowledge. Just pray as you see me as praying. When the time for prayer comes, one of you read the adhan. May your old lead you as imam!" which shows that men and women are subject to the same provisions regarding the manner of prayer without any restraints. Nevertheless, when we look at the provisions regarding the manner of prayer within the framework of Sunni figh sects; although there is no difference in terms of the wajib, sunnah or manners of the prayer, there are some differences in terms of the manner of the rituals. At this point, while there is no distinction between men and women in the provisions adopted by some sects, it emerges that there is a general or detailed distinction in some sects.

It is the Hanafis who make a gender-based distinction regarding the nature of certain rituals in prayer and place the most detailed provisions on the subject among sects. When Hanafi literature is examined; for women, it is seen that different provisions are made regarding the status of women in takbir, recitation, kneeling, prostrating, sitting between the two prostrating, tashahhud and the final sitting. In the Shafii and Hanbali literature, some superficial and a few judgments are mentioned about these situations. Malikis, on the other hand, with a 
perspective different from the other three sects, accepted that all kinds of verses and hadiths related to prayer are for both men and women. It is seen that those three sects other than Malikis try to base their views on some narrative accounts and rational inferences, on this matter the narrative account seems to be weak. Nevertheless, it is possible for the fuqaha that they attributed a figh value to such narrations according to some situations in which they consider hadiths and deeds are weak.

Apart from relying on some hadiths and accounts of the companions of prophet Muhammad in the decrees about the quality of the rituals in the prayers of women, it is seen that almost no evidence on the subject is mentioned in the Shafii literature, and it is partially included in the Hanafi and Hanbali literature. This situation, in our opinion, shows that the three sects make judgments based on some general principles. At this point, the expression أستر لها (more suitable for the veiling of women), which is mentioned in the three sects literature regarding the basis of the differences regarding the prayer of women, shows that the fuqaha considers the principle of compliance with veiling as a criterion in the judgment of women's prayer. In this study, it will be tried to examine the evidences and opinions expressed by the Fuqaha on the subject by revealing the motives of sects in the introduction of different provisions for women within the framework of the rituals of prayer.

Keywords: Fiqh, Prayer, Provision, Woman, Male.

\section{Namazın Rükünlerinde Kadın ve Erkeklere Yönelik Farklı Hükümler $\ddot{\mathrm{O} z}$}

Klasik fikıh literatüründeki ahkâm genel bir çerçevede değerlendirildiğinde; gerek hükme muhatap olma ve gerekse hükmün niteliği açısından ahkâmın ekseriyetinde kadın ve erkek arasında herhangi bir fark bulunmaz iken, ibâdât alanında zekat için kadının havâic-i asliyye sorumluluğunun bulunmaması, muâmelatta şahitlik ve ceza hukukunda diyet miktarı gibi bazı mevzularda kadın ve erkeğe yönelik farklı hükümler mevcuttur. Fıkhın ibâdât kısmında bulunan namaz ahkâmında da temelde kadın ile erkek arasında herhangi bir fark bulunmamaktadır. İslâm'da vücûbiyeti nasslarla belirtilen namazın şart ve rükünlerine ilişkin tafsilat ayetlerde zikredilmemiş, bu noktada ilgili hükümlere Hz. Peygamber'in (s.a.v.) sünneti ve sahabe uygulamaları kaynaklık etmiştir. Namaza ilişkin Hz. Peygamber'den (s.a.v.) gelen rivâyetlere bakıldığında namazın şartlarında ve rükünlerinde kadın ile erkek arasında temelde bir 
398 | F. BOZBAŞ / Namazın Rükünlerinde Kadın ve Erkeklere Yönelik Farklı Hükümler

farklılığın zikredilmediği, yalnızca namazın şartları içerisinde yer alan setr-i avretin niteliğine dair kadınlara hâs bazı rivâyetlerin mevcut olduğu görülmektedir.

Kadınların namazı hakkında setr-i avret haricinde, herhangi bir nass bulunmaması bir yana, "Ailelerinizin yanına dönün. Onlara dinî bilgileri öğretin. Beni nasıl namaz kılıyor olarak gördüyseniz öylece namaz kılınız. Namaz vakti geldiğinde içinizden biri ezan okusun. Yaşlınız da size imam olsun!" mânâsını taşıyan hadis de herhangi bir takyîd getirmeksizin namazın edâsına ilişkin kadın ile erkeğin aynı hükümlere muhatab olduğunu göstermektedir. Buna rağmen sünnî fıkıh mezhepleri çerçevesinde namazın edâsına yönelik hükümlere bakıldığında; namazın rükünleri ve rükünlerde riâyet edilmesi gereken vâcip, sünnet veya âdâbın ne olduğuna ilişkin herhangi bir farklılık söz konusu olmamakla birlikte, rükünlerin edâ niteliği açısından birtakım farklılıklar olduğu göze çarpmaktadır. Bu noktada bazı mezheplerin benimsedikleri hükümlerde kadın-erkek arasında bir ayrım gözetilmez iken, bazı mezheplerinkinde ise genel ya da mufassal bir ayrım olduğu ortaya çıkmaktadır.

Namazdaki bazı rükünlerin niteliğine ilişkin cinsiyet temelli bir ayrıma giderek mezhepler arasında mevzuya ilişkin en mufassal hükümlere yer veren Hanefîlerdir. Hanefî literatürü incelendiğinde; kadınlar için iftitâh tekbiri, kıraat, rükû, secde, celse, teşehhüt ve kade-i ahîredeki durumlarına ilişkin erkeklerden farklı hükümler serdedildiği görülmektedir. Şâfiî ve Hanbelî literatüründe de bu durumlara ilişkin yüzeysel ölçüde ve az sayıda bazı hükümlere temas edilmiştir. Mâlikîler ise diğer üç mezhepten farklı bir bakış açısıyla, ayet ve hadislerden yola çıkarak namaza ilişkin bütün ahkâmın hem erkek hem de kadınlara şâmil olduğunu kabul etmişlerdir. Mâlikîler dışındaki üç mezhebin, görüşlerini bazı rivayetler ve aklî istidlâller ile temellendirmeye çalıştıkları görülen bu meselede, temelde kendisiyle ihticâc edilen rivayetlerin zayıf oldukları görülmektedir. Buna rağmen, fukahânın zayıf hadisle amel konusunda göz önünde bulundurdukları bazı durumlardan hareketle bu nevi rivayetlere fıkhî bir değer atfetmiş olmaları mümkündür.

Kadının namazındaki rükünlerin niteliğine dair serdedilen hükümlerde bazı hadis ve sahâbe kavillerine istinâd edilmesi bir yana, Şafîi literatüründe konuya ilişkin neredeyse hiçbir naklî delilin zikredilmediği, Hanefî ve Hanbelî literatüründe ise kısmen yer bulduğu görülmektedir. Bu durum kanaatimizce bu konuda üç mezhebin daha ziyade genel bazı ilkelerden hareketle hüküm verdiklerini göstermektedir. Bu noktada kadının namazına ilişkin farklılıkların 
mesnedine ilişkin üç mezhep literatüründe zikredilen أستر لها (kadının tesettürüne daha uygundur)" ifadesi, fukahânın kadınların namazına dair ahkâmda tesettüre uygunluk ilkesini bir ölçüt olarak ele aldıklarını göstermektedir. Bu çalışmada, sünnî fıkıh literatüründeki veriler ele alınarak namazın rükünleri çerçevesinde kadınlara yönelik farklı hükümlerin serdedilmesinde fikıh mezheplerinin hangi saiklerden hareket ettikleri ortaya konularak fukahânın konuya ilişkin yaklaşımları irdelenmeye çalışılacaktır.

Anahtar Kelimeler: Fıkıh, Namaz, Hüküm, Kadın, Erkek.

\section{Giriş}

Klasik fikıh literatüründeki ahkâm genel bir çerçevede değerlendirildiğinde; gerek hükme muhatap olma ve gerekse hükmün niteliği açısından ahkâmın ekseriyetinde kadın ve erkek arasında herhangi bir fark bulunmaz iken, ibâdât alanında zekat için kadının havâic-i asliyye sorumluluğunun bulunmaması, muâmelatta şahitlik ve ceza hukukunda diyet miktarı gibi bazı mevzularda kadın ve erkeğe yönelik farklı hükümler mevcuttur. Fıkhın ibâdât kısmında bulunan namaz ahkâmına muhatap olma, namazın rükün ve şartlarının ne olduğuyla ilgili olarak kadın ile erkek arasında herhangi bir fark bulunmamakla birlikte, başta Hanefî mezhebi olmak üzere Şâfiî ve Hanbelî mezheplerinde namazın edâsına ilişkin olarak erkek ile kadın için bazı farklı hükümler mevcuttur.

Günlük hayatta yaygın bir tatbikî yönü olmakla birlikte fikhî arka planı pek de irdelenmeyen bu mevzu, tespit edebildiğimiz kadarıyla Munir Ahmad Munawwar'ın Mard Wa Aurat Ki Namaz Ke Farg Par Tafsili Jazia ${ }^{1}$ isimli eserinde müstakil bir çalışma konusu olarak ele alınmıştır. Müellifin konuya ilişkin mezheplerin görüşlerini ve istidlal ettikleri delillere yer verdiği bu eser haricinde mevzuya sadece fıkha müteallik bazı eserlerin satır aralarında değinildiğini² ve konuya dair hâssaten müstakil bir Türkçe çalışma

1 Munir Ahmad Munawwar, Mard wa aurat ki namaz ke farg par tafsili jazia (b.y.: Mektebetü Ehlü's-Sünne ve'l-Cemaat, ts.).

2 Vehbe Zuhaylî, el-Fıkhu'l-İslâmî ve edilletuh (Dımaşk: Dâru'l-fikr, 1405/1985), 728-751; Sâlih b. Fevzân Âl Fevzân, Teysîru Zâde'l-Müstakni fi'l-fikhi'l-Hạbelî (Beyrut: Dâru'lKütübi'l-'Ílmiyye, 1971), 1/92. 
bulunmadığını ifade etmek gerekir. Buradan hareketle elinizdeki çalışmada, hassaten Hanefî mezhebi müntesiplerinin mevzuya ilişkin âşina oldukları hükümlerin benimsenmesinde fıkıh mezheplerinin hangi saiklerden hareket ettikleri ortaya konularak fukahânın konuya ilişkin serdettikleri delil ve görüşler irdelenmeye çalışılacaktır.

\section{Ayet ve Hadislere Göre Kadın ile Erkeğin Namazındaki Farklılıklar}

İslâm'da namazın vücûbiyeti ayetlerden hareketle belirlenirken, şart ve rükünlerine ilişkin tafsilat ayetlerde zikredilmemiş; bu noktada konuya dair hükümlerin kaynağını Hz. Peygamber'in (s.a.v.) sünneti ve sahabe uygulamaları teşkil etmiştir. Namaza ilişkin Hz. Peygamber'den (s.a.v.) gelen rivâyetlere bakıldığında namazın şartlarında ${ }^{3}$ ve rükünlerinde ${ }^{4}$ hükme muhatap olma açısından kadın ile erkek arasında temelde bir farklılığın zikredilmediği, yalnızca namazın şartları içerisinde yer alan "setr-i avret" in niteliğine dair bazı rivâyetlerin mevcut olduğu görülmektedir. Bu minvalde, "Allah bülûğa ermiş kadının başörtüsüz kıldığı namazı kabul etmez" ${ }^{5}$ merfû hadisi doğrudan namazdaki setr-i avretin niteliğine delâlet etmekte iken, Hz. Peygamber'in (s.a.v.), huzuruna ince bir elbise ile giren Ebû Bekir'in kızı Esma'ya “Ey Esma! Kadın ergenlik çağına ulaşınca, -el ve yüzünü işaret ederek- şurası ve şurası müstesna artık onun yabancılar tarafından görülmesi doğru

3 Burada maksad; hadesten taharet, necasetten tahâret, setr-i avret, istikbâl-i kıble, vakit ve niyetten müteşekkil namazın şartlarına riâyet etme noktasında kadın ile erkek arasında hükmen bir farklılı̆̆ın olmamasıdır.

4 Burada kastedilen; iftitah tekbiri, kıyam, kıraat, rükû, secde, teşehhütten müteşekkil namazın rükünlerini yerine getirme hususunda kadın ile erkek arasında hükmen bir ayrımın söz konusu olmamasıdır.

[Ebû Abdillâh Ahmed b. Muhammed b. Hanbel eş-Şeybânî, Müsned, nşr. Şuayb Arnaût vd. (Beyrut: Müessesetü'r-Risâle, 1421/2001), 43/29 (No. 2592622); Ebû Dâvûd Süleymân b. el-Eş'as es-Sicistânî, es-Sünen, nşr. Şuayb el-Arnaût vd. (Dımaşk-Hicaz: Dâru'r-Risâleti'l-'Âlemiyye, 1430/2009), "Salat", 85 (No. 641); Ebû Îsâ Muhammed b. Îsâ et-Tirmizî, el-Câmi'u's-sahîh, nşr. Beşşâr Avvâd Ma'rûf (Beyrut: Dâru'l-Garbi'l-İslâmî, 1996), "Salat", 161 (No. 377); Ebû Bekr Ahmed b. Hüseyn elBeyhakī, es-Sünenü'l-kübrâ, thk. Muhammed Abdülkâdir Atâ (Beyrut: Dâru'l-kütübi'l'İlmiyye, 1424/2003), 3/118 (No. 5090); Abdullah b. Yûsuf Zeylaî, Naṣbü'r-râye liehâddîsi'l-Hidâye (Cidde: Dâru'l-Kıble li-Sekâfeti'l-İslâmiyye, ts.), 1/295]. 
olmaz." ${ }^{\prime 6}$ şeklindeki ifadelerle hicabın keyfiyyetini izah ettiği bazı rivâyetler de fukahâ tarafından namazdaki setr-i avreti tafsilatlı izah eden bir delil olarak isti'mal edilmiştir. Bu doğrultuda Hanbelî̂ mezhebinde namazda kadının yüzü, Şâfiî̀ ${ }^{8}$ ve Mâlikîi ${ }^{9}$ mezhebinde el ve yüzü dışındaki bütün vücudu için tesettür şart koşulmuşken, mezhepteki râcih görüşe göre Hanefîler namazda kadının el ve yüz ile birlikte ayağını da avret mahallinin şümûlünden çıkarmışlardır. ${ }^{10}$

Kadınların namazı hakkında setr-i avret haricinde, gerek namazın diğer şartlarının niteliğinde ve gerekse namazın rükünlerinin mahiyeti ve keyfiyetine yönelik herhangi bir nass bulunmaması bir yana, "Ailelerinizin yanına dönün. Onlara dinî bilgileri öğretin. Beni nasıl namaz kılıyor olarak gördüyseniz öylece namaz kılınız. Namaz vakti geldiğinde içinizden biri ezan okusun. Yaşlınız da size imam olsun!"11 hadisi de herhangi bir takyîd getirmeksizin namazın edâsına ilişkin kadın ile erkeğin aynı hükümlere muhatab olduğunu göstermektedir.

6 Ebû Dâvûd, “Libas”, 34 (No. 4104); Zeylaî, Naṣbü'r-râye, 3/299.

7 Muvaffakuddîn Ebû Muhammed Abdullâh b. Ahmed el-Cemmâîlî, Muginî (Riyâd: Dâru 'Âlemi'l-Kütüb, 1417/1997), 2/328.

8 Ebû İbrâhîm İsmâîl b. Yahyâ el-Müzenî, el-Mecmû' Şerhu'l-Mühezzzeb (Cidde: Mektebetü'l-İrşâd, ts.), 3/173; Ebü'l-Hasen Alî b. Muhammed el-Mâverdî, el-Hâavi'lkebîr, thk. Alî Muhammed Muavvız vd. (Beyrut: Dâru'l-Kütübi'l-'Illmiyye, 1414/1994), 2/167; Ebü'l-Kāsım Abdülkerîm b. Muhammed Râfiî, el-Fethu'l-'azîz fì Şerhị'l-Vecîz (eşŞerhu'l-kebîr), thk. Alî Muhammed Muavvız vd. (Beyrut: Dâru'l-Kütübi'l-'İlmiyye, 1417/1997), 2/33-34.

9 Ebü'l-Velîd Muhammed b. Ahmed el-Kurtubî, Bidâyetü'l-müctehid ve nihâyetü'lmukteșid (Kahire: Mektebetü İbn Teymiyye, 1415/1995), 1/283; Abdurrahmân b. Ahmed el-Bagdâdî, İrşâdü's-sâlik ilâ eşrefi'l-mesâlik (Kahire: Dâru'l-Fazîle, ts.), 36; Ebû Abdillâh Muhammed b. Ahmed ed-Desûkī, Hậşiye 'ale'ş-Şerhị'l-kebîr (b.y: Dâru İhyâi Kütübi'l'Arabiyye, ts.), 1/214, 216.

10 Zeynüddîn b. İbrâhîm b. Muhammed el-Misrî, el-Eşbâh ve'n-Nezââir (Beyrut: Dâru'1Kütübi'l-'İlmiyye, 1419/1999), 278; Muhammed Emîn b. Ömer b. Abdilazîz edDımaşkī, Reddü'l muhtâr 'ale'd-Dürri'l-muhtâr (Riyâd: Dâru 'Âlemi'l-Kütüb, 1423/2003), 9/531; Burhanpurlu Şeyh Nizâmüddîn vd., el-Fetâva'l-hindiyye (Beyrut: Dâru'lKütübi'l-'Illmiyye, 1421/2000), 1/58.

[Ebû Abdillâh Muhammed b. İsmâil el-Buhârî, el-Câmi'u'ș-ṣhîhh. (Dımaşk-Beyrut: Dâru İbn Kesîr, 1423/2002), “Ezan”, 18 (No. 631); Beyhakī, Sünen, 2/486-487 (No. 3856)]. 
Buna rağmen sünnî fıkıh mezheplerinin literatürü incelendiğinde; Mâlikîler haricindeki üç mezhebin, bazı rivâyetlerin yanı sıra kabul ettikleri genel bazı ilkelerden hareketle birtakım farklılıkların mevcudiyetini benimsemişlerdir.

\section{Mezheplere Göre Namazın Edasına İlişkin Kadın ve Erkeklere Yönelik Farklı Hükümler}

Sünnî fıkıh mezhepleri çerçevesinde namazın edâsına yönelik hükümlere bakıldığında; namazın rükünleri ve rükünlerde riâyet edilmesi gereken vâcip, sünnet veya âdâbın ne olduğuna ilişkin herhangi bir farklılık söz konusu olmamakla birlikte, rükünlerin edâ niteliği açısından birtakım farklılıklar olduğu göze çarpmaktadır. Bu noktada bazı mezheplerin benimsedikleri hükümlerde kadın-erkek arasında bir ayrım gözetilmez iken, bazı mezheplerinkinde ise genel ya da mufassal bir ayrım olduğu ortaya çıkmaktadır.

Namazdaki bazı rükünlerin niteliğine ilişkin cinsiyet temelli bir ayrıma giderek mezhepler arasında mevzuya ilişkin en mufassal hükümlere yer veren Hanefîlerdir. Hanefî literatürü incelendiğinde; kadınların erkeklere imam olamaması, ${ }^{12}$ kendi aralarında cemaat oluşturmalarının $^{13}$ ve ezan okuma ile kamet getirmelerinin mekrûh oluşu, $^{14}$ evde namaz kılmalarının daha faziletli sayılması, ${ }^{15}$ mekruh olmasına rağmen kendi aralarında oluşturdukları cemaatte kadın imamın önde değil de aralarında durması, ${ }^{16}$ imamın yanıldığını hatırlatmak üzere "Subhânallah" demek yerine el çırpmaları, ${ }^{17}$ Cuma ve bayram namazı kılmalarının gerekli olmadığ ${ }^{18}{ }^{18}$ sabah namazını geciktirmelerinin (isfâr) müstehab olmayışı ${ }^{19}$ gibi genel farklılıkların yanı sıra, namazın

12 Ebû Muhammed Osman b. Ali b. Mihcen ez-Zeylaî, Tebyînü'l-hakāīik. (Multan: Mektebetü İmdâdiyye, ts.), 1/118; Zeynüddîn b. İbrâhîm b. Muhammed el-Misrî, elBahrü'r-râ'ik. (Dâru'l-Kütübi'l-'İlmiyye, 1418/1997), 1/561; a.mlf., Eşbâh, 278; İbn Âbidîn, Reddü'l muhtâr, 2/211.

13 Zeylaî, Tebyînü'l-hakā̄ik, 1/118; İbn Nüceym, Eşbâh, 278.

14 İbn Nüceym, Eşbâh, 278.

15 İbn Nüceym, Eşbâh, 279.

16 Zeylaî, Tebyînü'l-hakā̄ik, 1/118; İbn Nüceym, Bahrü̈rr-râaik, 1/561; a.mlf., Eşbâh, 278; İbn Âbidîn, Reddü'l muhtâr, 2/211.

17 İbn Nüceym, Eşbâh, 278; İbn Âbidîn, Reddü'l muhtâr, 2/211.

18 İbn Nüceym, Eşbâh, 279; İ̉n Âbidîn, Reddü'l muhtâr, 2/211.

19 İbn Nüceym, Bahrü'r-râoik, 1/561; İbn Âbidîn, Reddül muhtâr, 2/211. 
şartlarından setr-i avretin niteliğine ${ }^{20}$ dair de farklı hükümlerin mevcut olduğu görülmektedir.

Hanefî literatüründe namaza müteallik meselelerde kadın ve erkekler arasındaki farklara temas edinen Tebyîn ${ }^{21}$ ve Bahrür'r-râa $i k^{\prime}$ te 10,22 Eşbâh'ta $18,{ }^{23}$ Reddü'l-muhtâr' da 25 aded $^{24}$ hüküm zikredilmektedir.

Şâfiî mezhebinde kadının namazına ilişkin olarak namazı evde kılmalarının müstehab oluşu, ${ }^{25}$ kendi aralarında oluşturdukları cemaatte imamın önde değil de aralarında durması, mahremi olan erkeklerle cemaat halinde namaz kıldıklarında arkada durmaları, ${ }^{26}$ mahremi olmayan erkeklerle namaz kıldıklarında en arkadaki safta durmalarının efdal oluşu ${ }^{27}$ gibi hükümler benimsenmiş olmasının yanı sıra, rükünlerin edâsına ilişkin kadın ile erkeğin namazı arasında talî bazı hükümler benimsendiği görülmektedir.

Hanbelî mezhebinde, kadınlar imam oldukları takdirde ön safın ortasında durmaları gerektiği gibi erkeklerinkinden farklı bazı hükümler de benimsenmiş olmakla birlikte, ${ }^{28}$ kural olarak namazın edasına ilişkin kadın ile erkek arasında temelde bir farklılığın bulunmadığı kabul

20 Hanefîlere göre; namazda erkeğin avret mahalli göbek ile diz kapağı (dahil) arası iken, kadının el, yüz ve ihtilaflı olmakla birlikte ayağı dışındaki bütün vücudu avret hükmündedir. Bk. İbn Nüceym, Bahrü̈'r-râaik, 1/468-469; a.mlf., Eşbâh, 278; İbn Âbidîn, Reddü'l muhtâr, 2/76.

21 Zeylâi, Tebyînül-hakāāik, 1/118.

22 İbn Nüceym, Bahrü̈r $r$ râaik, 1/561.

23 İbn Nüceym, Eşbâh, 278-279.

24 İbn Âbidîn, Reddü'l muhtâr, 2/211.

25 Bu meseleyi Şâfiîler Abullah b. Mes'ud'dan nakledilen, Hâkim'in sahih olduğunu

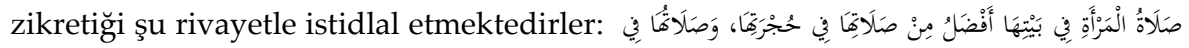
[Kadının özel odasında kıldığ1 namaz , (evin) salonunda kıldığ1 namazından, (eşyalarının gizlendiği) daha özel odada kıldığı namaz da özel odasında kıldığı namazdan daha efdaldir.]. Bk. Ebû Dâvud, "Salât", 54 (No. 570); Ebû Abdillâh Muhammed b. Abdillâh el-Hâkim en-Nîsâbûrî, el-Müstedrek, thk. Mustafa Abdülkâdir Atâ (Beyrut: Dâru'l-Kütübi'l-'İlmiyye, 1422/2002), 1/328; Beyhakî, Sünen, 3/188.

26 Şâfiîler bu meselede Ebû Hureyre' den nakledilen şu rivayeti hüccet olarak zikrederler: "Kadınların saflarının en hayırlısı en sondaki saf, en kötüsü ise ilk saftır..." Müslim, "Salât", 28 (No. 132).

27 Mâverdî, Hậvi'l-kebîr, 2/163.

28 İbn Kụâme, Muginî, 2/271. 
404 | F. BOZBAŞ / Namazın Rükünlerinde Kadın ve Erkeklere Yönelik Farklı Hükümler

edilmiştir. ${ }^{29}$ Buna rağmen Hanbelî literatürüne bakıldığında; Hanefî ve Şâfiîlerin de hareket noktası olan kadının tesettürüne daha ihtimam gösterebilmesi ilkesine ma'tuf bazı farklı hükümlerin varlığı göze çarpmaktadır.

Kadınların namazı edâ niteliğine ilişkin hususen Hanefîlerden farklı bir bakış açısına sahip olan Malikîler ise, İmâm Mâlik'ten iktibasla namazın secde, celse ve teşehhüt gibi rükünlerinin niteliğine dair kadınerkek arasında bir fark olmadığını ifade etmektedirler. ${ }^{30}$

Çalışmanın bundan sonraki kısmında namazın rükünlerine dair erkek ile kadın arasında farklılıkların olduğu kabul edilen hükümlere ve bu hükümlerin delillere yer verilerek genel bir değerlendirme yapılmaya çalışılacaktır.

\section{1. İftitah Tekbiri}

2.1.1. Hanefîlerde kabul edilen hüküm gereğince iftitah tekbiri alan kadın, erkeğin yaptığından farklı olarak ellerini kulakların hizasına değil, parmak uçları omuz hizasına gelecek ölçüde kaldırır, tekbirin akabinde göğsünün üzerine gelecek şekilde sağ elini sol elinin üzerine koyar, kavrayıp tutmaz. ${ }^{31}$ İbn Âbidin (öl. 1252/1836) bu hükme, ellerini giysisinin yeninden (manşet) çıkarmamasını da ilave etmiştir. ${ }^{32}$ Hasan eş-

29 İbn Kụdâme, Muginî, 2/258.

30 Ebû Saîd Abdüsselâm b. Saîd et-Tenûhî, el-Müdevvenetü'l-kübrā (b.y.: Vizâretü'lEvkâfi's-Suûdiyye, 1324/1906), 1/73; Ebû Ömer Yûsuf b. Abdillâh b. Muhammed b. Abdülber en-Nemerî, el-Kâfí fí füru'i'l-Mâlikîyye, thk. Muhammed el-Morîtânî (Riyad: Mektebetü'1-Riyâdi'l-Hadîse, 1398/1978), 1/204.

31 Ebü'l-Hasen Burhânüddîn Alî b. Ebî Bekr b. Abdilcelîl Mergīnânî, Hidâye (Karaçi: İdâretü'l-Kur'ân ve'l-'Ulûmi'l-İslâmiyye, 1417/1997), 1/309; Ebü'l-Fazl Mecdüddîn Abdullāh b. Mahmûd el-Mevsılî, el-ïhtiyâr li-tâ'lili'l-Muhtâr (Beyrut: Dâru'l-Ma'rife, 1423/2002), 1/67; Ebü'l-Abbâs Muzafferüddîn Ahmed b. Alî el-Bağdâdî, Mecma'u'lbahreyn ve mülteka'n-neyyireyn (Beyrut: Dâru'l-Kütübi'l-'Illmiyye, 1426/2005), 119; Zeylaî, Tebyinn̈̈l-hakāỉk, 1/109, 118; Kemâlüddîn Muhammed b. Abdilvâhid es-Sivâsî, Fethu'l-kadîr li'l-'âcizi'l-fakị̂r (Beyrut: Dâru'l-Kütübi'l-'Illmiyye, 1424/2003), 1/288; Molla Hüsrev, Dürerü'l-hükkâm fi şerhi Gureri'l-ahkâm (Karaçi: Mîr Muhammed Kütüphâne, ts.), 1/66; İbn Nüceym, Bahrü̈r-râoik, 1/561; a.mlf., Eşbâh, 278-279; İbn Âbidîn, Reddü'lmuhtâr, 2/211. Tebyîn'de, mezhepte hükmün hür kadınlara ilişkin olup köle kadınların erkeklerle aynı şekilde iftitah tekbiri alacağına ilişkin bir görüşün olduğu da zikredilir. Bk. Zeylaî, Tebyînü'l-hakā̄ik, 1/109; Ebû Bekr b. Muhammed b. Ali el-Haddâdî, Sirâcü'lvehhâc (Dımaşk: Dâru'l-Kütübi'z-Zâhiriyyeti'l-Ehliyye, 2534), 163b.

32 İbn Âbidîn, Reddü'l-muhtâr, 2/211. 
Şeybânî' den (öl. 189/805)gelen bir rivayete göre Ebû Hanife, kadının elleri avret olmaması hasebiyle tekbirin alınış şeklinde erkekle kadın arasında fark bulunmadığını zikretmiş olsa da kaynaklarda ilk görüşün daha doğru olduğu ifade edilmiştir. ${ }^{33}$ Hükmün delili bağlamında herhangi bir nass zikretmeyen Hanefîler, Muhammed b. Mukâtil er-Râzî'nin (öl. 248/862) Hanefî fukahadan birinci görüş doğrultusunda rivayetlerde bulunduğunu ifade etmekle iktifâ etmişlerdir. ${ }^{34}$

Hanefîlerin ifadelerine bakıldığında hükmün daha ziyade kadının namazda riâyet etmesi gereken tesettürüne daha uygun olmasiyla ilişkilendirildiği söylenebilir. ${ }^{35} \mathrm{Bu}$ noktada kanaatimizce Hanefîler, kadının ellerini daha yukarıya kaldırdığı taktirde örtünmesi gereken yerlerin açlabileceği ihtimaline binâen bu hükmü benimsemişlerdir. Diğer yandan kadının iftitah tekbiri alışına ilişkin sahâbeden Ümmü'dDerdâ el-Eslemiyye (öl. 30/650) ${ }^{36}$ ile Hafsa bnt. Sîrîn (öl. 101/719), ${ }^{37}$ tâbiûndan Âtâ b. Ebû Rebâh (öl. 114/732), ${ }^{38}$ Hammâd b. Ebû Süleymân (öl. 120/738) ${ }^{39}$ ve Zührî́'den (öl. 124/742), ${ }^{40}$ Hanefîlerin görüşüne paralel doğrultuda rivayet edilen birtakım fetva ve uygulamalar mezhepte benimsenen bu hükmü teyit ediyor olsa da Kütüb-i Sitte muhtevâsında da bulamadığımız bu rivâyetlerin Hanefîlerce istidlâle elverişli görülmemiş olması muhtemeldir.

2.1.2. Hanbelî mezhebinde kadınların tekbir esnasında ellerini kaldırmalarıyla ilgili olarak Ahmed b. Hanbel'den gelen iki rivâyetten birine göre kadın ellerini kaldırır. Zira hakkında tekbir farz kılınan kişinin

33 Merginânî, Hidâye, 1/309; Alâüddîn Ebû Bekr b. Mes'ûd b. Ahmed el-Kâsânî, Bedâ'i 'u'ssanấ'i' fî̀ tertîbi'ş-şerâa'i' (Beyrut: Dâru'l-Kütübi'l-'Illmiyye, 1424/2003), 2/24; Zeylaî, Tebyînü'l-hakāik, 1/109; İbnü'l-Hümâm, Fethu'l-kadîr, 1/288 İbrâhîm b. Muhammed b. İbrâhîm el-Halebî, Gunyetü'l-mütemellî fî șerhị Münyeti'l-Musallî: Halebî Kebîr (b.y.: Dâru Saâde, 1325), 300.

34 Kâsânî, Bedâ'i'u's'ṣanâ'i', 2/24; İbnü'l-Hümâm, Fethu'l-kadîr, 1/288.

35 Kâsânî, Bedâ'i'u's-ṣanâ'i', 2/24; Mevsılî, el-İhtiyâr, 1/67; Zeylaî, Tebyînü'l-hakạ̄ìk, 1/109; İbnü'l-Hümâm, Fethu'l-kadîr, 1/288.

36 Ebû Bekr Abdullâh b. Muhammed b. Ebî Şeybe el-Kûfî, el-Musannef (Riyad: Mektebetü'r-Rüşd, 1425/2004), 2/69 (No. 2482).

37 İbn Ebû Şeybe, Muṣannef, 2/70 (No. 2487).

38 İbn Ebû Şeybe, Musannef, 2/70 (No. 2483, 2486).

39 İbn Ebû Şeybe, Musannef, 2/70 (No. 2485).

40 İbn Ebû Şeybe, Musannef, 2/70 (No. 2484). 
406 | F. BOZBAŞ / Namazın Rükünlerinde Kadın ve Erkeklere Yönelik Farklı Hükümler

erkekler gibi ellerini de kaldırması gerekir. Meseleye ilişkin tek fark, kadınların erkekler gibi omuzlara kadar değil, bundan daha az ölçüde kaldırmasına ilişkindir. Sahâbe hanımlarından Ümmü'd-Derdâa ${ }^{41}$ ile Hafsa b. Sîrîn'in ${ }^{42}$ de tekbir sırasında ellerini kaldırdıkları rivayet edilmektedir. İ̉nn Hanbel'den gelen diğer rivayete göre ise; kadının tekbir sırasında ellerini kaldırması, (el, kol gibi) avret mahallinin açılmasına sebebiyet vereceğinden kadın için gerekli değildir. ${ }^{43}$

\subsection{Kiraat}

2.2.1. Hanefî mezhebinde kıraatin keyfiyetine ilişkin kadınla erkek arasındaki tek fark; sabah, akşam ve yatsı namazlarından müteşekkil olan cehrî namazlarda kadının kıraatinin sesli olmamasıdır. Bu konuda Hanefî fukahasının ifadelerine bakıldığında, nassa dayalı bir istidlâl olmaksızın, her ne kadar ihtilaflı olsa da kadının sesinin namazda avret olacağına ilişkin görüşten hareketle böyle bir hüküm verildiği görülmektedir. ${ }^{44}$

2.2.2. Şâfiî mezhebinde kıraate ilişkin erkeklerden farklı olarak kadınlar, cehrî namazlarda mahremi olmayan erkeklerin yanında gizli (hafî) kıraat yaparlar. ${ }^{45}$ Kadının sesi mezhepteki râcih görüşe göre avret kabul edilmemesine rağmen Şâfiîler tarafından benimsenen bu hüküm ${ }^{46}$ fitne endişesi ile ilişkilendirilmiştir. ${ }^{47}$

2.2.3. Hanbelî mezhebinde yanında yabancı bir erkek bulunduğu takdirde kadınlar için cehrî kıraat uygun değildir, hafî kıraatte bulunmalıdırlar. ${ }^{48}$

2.2.4. Mâlikî mezhebinde namazın rükünlerine ilişkin kadın ile erkek arasında bir farklılık kabul edilmemiş olmakla birlikte, Mâlikî literatürün satır aralarında cehrî kıraat konusunda kadın-erkek arasında farklılık arzeden bir hükmün mevcut olduğunu tespit ettiğimizi ifade etmek gerekir. Bu bağlamda; mezhepte benimsenen görüşe göre erkekler

41 İbn Ebû Şeybe, Mușannef, 2/69 (No. 2482).

42 İbn Ebû Şeybe, Musannef, 2/70 (No. 2487).

43 İbn Kudâme, Muginî, 2/139.

44 İbn Nüceym, Bahrü̈r-rârik, 1/561; a.mlf., Eşbâh, 278; İbn Âbidîn, Reddül muhtâr, 2/78, 211.

45 Müzenî, Mecmû', 3/355-356; Mâverdî, Hâ̂vi'l-kebîr, 2/162.

46 Müzenî, Mecmû', 3/356.

47 Mâverdî, Hâavi'l-kebîr, 2/162; Zuhaylî, Fıkhu'l-İslâmî ve edilletuh, 747.

48 Mansûr b. Yûnus b. Salâhiddîn el-Buhûtî, Keşşâfu'l-ḳnâ' 'an metni'l-íknâ' (Beyrut: 'Âlemü'l-kütüb, 1403/1983), 5/15. 
için cehrî kıraatin a'zamî ses seviyesinde bir sınır yokken, kadınlar için cehrî kıraatin tek bir seviyesi bulunmaktadır. $\mathrm{O}$ da en fazla kendilerinin duyabileceği bir ses tonunu ifade etmektedir. ${ }^{49}$

\subsection{Rükû ve Secde}

2.3.1. Hanefî kaynaklarında zikredildiği üzere rükûda kadın, parmakları dizlerinin üstüne gelecek şekilde ellerini uyluklarının üstüne koymalı, el parmaklarının arasını açmamalı, ${ }^{50}$ kollarını erkekler gibi dik tutmamalıdır. ${ }^{51}$ Bunların yanı sıra az eğilerek dizlerini hafif bükmesi ve topuklarını birleştirmesi gerektiği de zikredilmiştir. ${ }^{52}$ Hanefî fukahasının bu meseleye ilişkin izahları, tesettüre riayet ilkesinden hareketle bu hükme ulaştıklarını göstermektedir. ${ }^{53}$

Hanefî kaynaklarında kadının secde şekli ise; derli toplu bir şekilde olması, kalçasını yukarıya kaldırmayarak karnını uyluklarına yapıştırması, kollarını erkeklerin yaptığının aksine iki yana açmayarak yere ve vücudunun iki yanına birleştirmesi gerektiği şeklinde zikredilmiştir. ${ }^{54}$

Secdeye ilişkin rivayet edilen "Sizden biriniz secde ettiğinde kollarını köpeğin yere yayması gibi yaymasın." 55 hadisinin muhatabının erkekler olduğunu zikreden Hanefîler, ${ }^{56}$ kadınların secde ediş keyfiyeti

49 Kadının hafî kıraatinin derecesi ise râcih görüşe göre dilini hareket ettirmesidir. Bk. Sahṇūn, Müdevvene, 1/65; Desûkī, Hâsşiye, 1/242-243.

50 Zeylâ̂, Tebyînül-hakā̄ik, 1/118; Haddâdî, Sirâcü'l-vehhâc, 163b; İbn Nüceym, Bahrü'rrẩik, 1/561; a.mlf., Eşbâh, 278; İbn Âbidîn, Reddü'l muhtâr, 2/211.

51 Burhanpurlu Şeyh Nizâmüddîn vd., Fetâva'l-hindiyye, 1/74; İbrâhîm el-Halebî, Halebî Kebîr, 316.

52 İbrâhîm el-Halebî, Hạebî Kebîr, 315-316; Reddü'l muhtâr, 2/211.

53 İbrâhîm el-Halebî, Halebî Kebîr, 316; İbn Âbidîn, Reddü'l muhtâr, 2/211.

54 Ebû Bekr Muhammed b. Ebî Sehl es-Serahsî, el-Mebsût (Beyrut: Dâru'l-Ma'rife, 1409/1989), 1/23; Kâsânî, Bedâ'i'u'u'ș-sanâ'i', 2/62; Merginânî, Hidâye, 1/333; İbnü's-Sââtî, Mecma'u'l-bahreyn, 124; Zeylaî, Tebyînü'l-hakā̄ik, 1/118; Hạddâdî, Sirâcü'l-vehhâc, 163a; Molla Hüsrev, Dürerü'l-hü̈kkâm, 1/72; İbn Nüceym, Bahrü'r-rârik, 1/561; a.mlf., Eşbâh, 278; İbn Âbidîn, Reddü'l muhtâr, 2/211; Şeyh Nizâmüddîn, Fetâva'l-hindiyye, 75; İbrâhîm el-Halebî, Halebî Kebîr, 322.

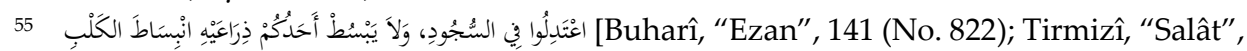
90 (No. 275); Ahmed b. Hanbel, Müsned, 3/305). Benzer lafızlarla başka bir rivâyet için bk. Ebû Dâvûd, "Salât", 157 (No. 897)].

56 Kâsânî, Bedâ'i' 'u's-sanân'i', 2/61-62. 
408 | F. BOZBAŞ / Namazın Rükünlerinde Kadın ve Erkeklere Yönelik Farklı Hükümler

ile ilgili olarak Yezîd b. Ebî Habîb'ten rivâyet edilen, Ebû Dâvud'un mürsel hadisler arasında yer verdiği şu rivayetle ihticac etmişlerdir:57

Hz. Peygamber namaz kılan iki kadının yanına uğrayıp (onlara şöyle) demiştir: "Secde ettiğiniz vakit büzüşün. Kadın bu (secde) konuda erkek gibi değildir." 58

Hanefîler kadının secde halinde bu şekildeki duruşunun efdaliyetine yönelik Hz. Ali'nin farkı lafızlarla zikredilen "Kadınlar namaz kıldıklarında derli toplu hareket etsinler, uyluklarını (vücutlarına) bitiştirsinler." kavlini de delil nev'inde beyan etmiş olsalar da Beyhakî'nin bu meseleye ilişkin Hz. Ali'den nakledilen iki rivayetin de zayıf olarak tavsif ettiğini ifade etmek gerekir. ${ }^{59}$

Ayrıca hükme delâlet yönünden sarîh bir delil olmasa da, "Kadın avrettir (örtünmesi gereken kimsedir)." ${ }^{\prime 60}$ merfû hadisine de istinâd eden Hanefîler, ${ }^{61}$ secdede bu tarz oturuşun kadının tesettürüne riâyeti açısından daha münasip olduğunu ifade etmişlerdir. ${ }^{62}$

2.3.2. Kadının secdedeki durumuna ilişkin Şâfii literatüründe, İmam Şafiinin, kadının tesettürünü en iyi şekilde muhafaza edebilmesi

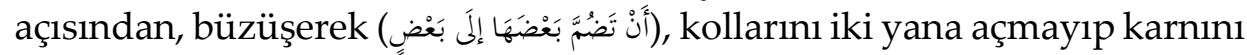
uyluklarına bitiştirmek suretiyle oturmasının daha uygun bulduğuna yönelik (احب للمرأة ...) ifadeleri, ayrıca rükû, celse gibi namazın diğer erkanında da kadının mümkün olduğu kadar tesettüre riayet ilkesini

57 Zeylaî, Tebyînü'l-hakā̄ik, 1/118; İbn Nüceym, Bahrü'r'r-râoik, 1/561

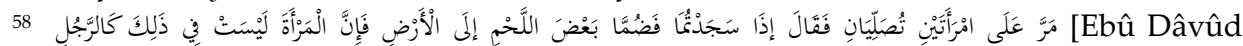
Süleymân b. el-Eş‘as es-Sicistânî, el-Merâsîl, nşr. Abdülazîz İzzüddîn es-Sirvân (Beyrut: Dâru'l-kalem, 1406/1986), 103 (8); Beyhakī, Sünen, 2/315 (No. 3201)].

59 Rivayetlerin biri Beyhakî’nin Sünen'inde “"اذا سجد المرأة فلتضم فخذيها" (Beyhakī, Sünen, 2/314 (No. 3197) olarak zikredilirken, diğer rivayet de başka kaynaklarda şu şekilde yer

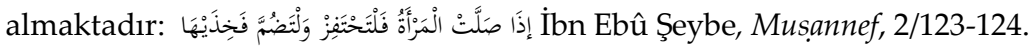

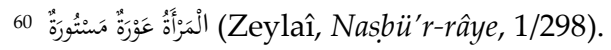

61 Serahsî, el-Mebsût, 1/23.

49 Serahsî, el-Mebsût, 1/23; Kâsânî, Bedâ'i'u's-șanâ'i', 2/62; Merginânî, Hidâye, 1/333; İbnü's-Sââtî, Mecma'u'l-bahreyn, 561; Hạdâdî, Sirâcü'l-vehhâc, 163a; İbn Âbidîn, Reddü'l muhtâr, 2/211. 
ölçüt almasının efdaliyeti üzerinde duran beyanları mezhep görüşü olarak zikredilmektedir. ${ }^{63}$

2.3.3. Hanbelî mezhebinde kadının rükû ve secde haline ilişkin

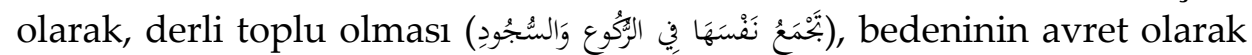
kabul edilen kısmının görülebileceği endişesiyle kollarını erkeklerin yaptığı gibi iki yana açmamasının daha uygun olduğu ifade edilmiştir. ${ }^{64}$

Hanbelîler kadınların rükû ve secde haline ilişkin serdettikleri görüşlerini Hanefî mezhebinde de delil nev'inde zikredilen, Beyhakî'nin zayıf olarak tavsif ettiği, ${ }^{65} \mathrm{~Hz}$. Ali'nin "Kadınlar namaz kıldıklarında derli toplu hareket etsinler, uyluklarını (vücutlarına) bitiştirsinler." ${ }^{66}$ kavliyle ihticâc etmişlerdir.

\subsection{Celse, Teşehhüt ve Ka'de}

2.4.1. Hanefîler kadının namazda celse, teşehhüt ve kâde-i ahîrede erkeklerin oturuş şeklinden (iftiraş) farklı olarak teverrük halinde oturmaları gerektiğini zikretmişlerdir. ${ }^{67}$ Teverrükten maksat; sol kalçanın üzerine oturarak iki ayağ 1 sağ tarafa doğru yan yatırıp çıkarmaktır.68 Ayrıca bazı kaynaklarda setr-i avretin namazın bir farzı oluşundan hareketle, kadının sünnet olan oturma şeklini tatbik etmesindense tesettüre riâyet etmesinin daha münasip olduğu zikredilmiştir. ${ }^{69}$

Hanefîlerce zikredilen bu hükmün Şâfiî ve Mâlikîlerin görüşüyle aynı doğrultuda olduğu ifade edilmelidir. Zira namazın rükünlerinde kadın-erkek farklılığının gözetilmediği Mâlikîlerde gerek ka'de gerekse

63 Ebû Abdillâh Muhammed b. İdris eş-Şâfiî, el-Ümm (Kahire: Dâru'l-Vefâ, 1422/2000), 2/264-265; Müzenî, Mecmî', 3/380-381, 406; Ebû Zekeriyyâ Yahyâ b. Şeref en-Nevevî, Ravzatü't-tâlibîn (Beyrut: el-Mektebü'l-İslâmî, 1412/1991), 1/259; Râfiî, Şerhu'l-kebîr, $1 / 524$.

64 Ebü'l-Kāsım Ömer b. Hüseyin b. Abdillâh el-Hırakī, Muhtasaru'l-Hırakīi(Tanta: Dâru'sSahâbe, 1413/1993), 24; İbn Kudâme, Muginî, 2/258; Ebü'n-Necâ Mûsâ b. Ahmed b. Mûsâ el-Haccâvî, İknâ' li-tâlibi'l-intifâ' (Beyrut: Dâru'l-Ma'rife, ts.), 1/125.

65 Beyhakī, Sünen, 2/314 (No. 3197).

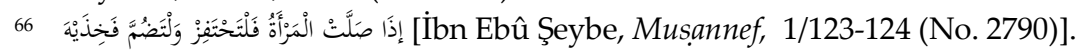

67 Mergīnânî, Hidâye, 1/337; Zeylaî, Tebyînü'l-hakā̄ik, 1/118; Haddâdî, Sirâcü'l-vehhâc, 166a; İbn Nüceym, Bahrü'r-rầik, 1/561; a.mlf., Eşbâh, 279; İbn Âbidîn, Reddü'l muhtârr, 2/211; Şeyh Nizâmüddîn, Fetâva'l-hindiyye, 75.

68 Mergīnânî, Hidâye, 1/337; Haddâdî, Sirâcü'l-vehhâc, 166a.

69 Hạdâdî, Sirâcü'l-vehhâc, 166a. 
celsede teverrük oturuşu benimsenmişken, ${ }^{70}$ celse veya ka'dedeki oturuşa ilişkin muhtelif bir hükmün yer almadığı Şâfiî mezhebine göre kadınların erkekler gibi kade-i ûlâda iftiraş, kade-i âhirede ise teverrük halinde oturmaları gerekir. ${ }^{71}$ Görüldügü üzere her ne kadar teverrük adı verilen oturuş şeklinin mahiyeti Hanefî mezhebi ile diğer mezhepler arasında kısmî bir farklılık arzetse de, ${ }^{72}$ nihâî noktada kadınların oturuşuyla ilgili Hanefîlerce tasvîb edilen hükümle örtüştügü görülmektedir.

Bazı Şâfiî kaynaklarında ayrıca oturarak namaz kılan kadının bağdaş kurarak oturması gerektiğine de temas edilmektedir. ${ }^{73}$

2.4.2. Hanbelî mezhebinde kadının celsedeyken bağdaş

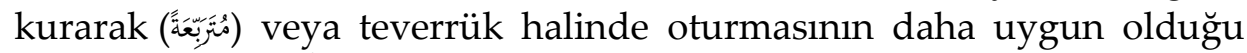
kabul edilmiş, ${ }^{74}$ İbn Hanbel'in kadının celsede iken teverrük halinde (السدل) oturuşunu daha münasip gördügüü (أَعْجَبُ إلَِّ) rivayet edilmiştir.75

Hanbelîler ayrıca İbn Ömer'in, kadınların namazda bağgdaş kurarak oturmalarını emrettiğine yönelik kavlini görüşlerini teyit amacıyla beyan etmiş olsalar $\mathrm{da}^{76}$ konuya ilişkin rivayetlerin yer aldığ 1 kaynaklarda bu rivayete rastlamadığımızı belirtmek gerekir.

\subsection{Namazda Uyarı İçin “Sübhânallah” Demek}

2.5.1. Namazın doğrudan edâ şekline yönelik bir farklılık olmasa da kadınların namazına ilişkin kabul edilen tâlî bir diğer farklılık da cemaatle namaz kılarken hata yapan imama yanıldığını fark ettirmek amacıyla erkekler "Sübhânallah" derken kadınların ellerini birbirine vurmalarının gerektiğidir. ${ }^{77}$ Hanefî literatüründe bu konuya kadının

70 Sạnụun, Müdevvene, 1/73; İbn Abdülber, Kâfî, 1/204.

71 Müzenî, Mecmû', 3/429-431.

72 Farklılık; teverrük oturuşunun, Hanefîlerde sağ ayağın yandan çıkarılması, Mâlikîlerde kıble istikametine doğru dikilmesine yönelik kabulden kaynaklanmaktadır. Dört fıkıh mezhebinin teverrük yorumu için bk. Merginânî, Hidâye, 1/337; Hạddâdî, Sirâcü'l-vehhâc, 166a; Müzenî, Mecmô', 3/430; Sạnnūn, Müdevvene, 1/73; Ebü'l-Berekât Mecdüddîn Abdüsselâm b. Abdillâh el-Harrânî, elMuharrer fi'l-fikh 'alâ mezhebi'l-İmâm Ahmed b. Hạbel (Beyrut: Dâru'l-Kitâbi'l-'Arabî, 1378/1959), 1/66.

73 Mâverdî, Hậvi'l-kebîr, 2/162.

74 Hırakī, Muhtasaru'l-Hırakī, 24; İ̉n Kudâme, Mugnnî, 2/258; Haccâvî, İknấ', 1/125.

75 İbn Kụdâme, Muginî, 2/258.

76 İbn Kưâme, Muginî, 2/259.

77 İbn Nüceym, Eşbâh, 278; İ̉n Âbidîn, Reddü'l muhtâr, 2/211. 
sesinin avret olup olmaması yönünden değinilmiştir. Mevzuya ilişkin ihtilaf bir yana, ${ }^{78}$ Hanefîlerden kadının nağmeli sesini namazda veya namaz dışında avret olarak kabul edenler, Hz. Peygamber'in (s.a.v.) "Sübhânallah erkekler için, el çırpma kadınlar içindir."79 merfû hadisini delil zikrederek, kadının sesinin avret olma hususiyetini izah etmektedir. ${ }^{80}$ Kadının sesini avret kabul etmeyenler kadının tesbîhte bulunmamasını fitne endişesi ile izah etmişlerdir. ${ }^{81}$

2.5.2. Şâfiî mezhebinde cemaatle namaz kılarken hata yapan imama yanıldığını farkettirmek amaciyla erkekler "Sübhânallah" derken kadınlar ellerini birbirine vururlar. Alkışlama (التصفيق) olarak ifade edilen bu hareketin ne şekilde yapılacağı mezhepte tercih edilen görüşe göre önemli değildir. Buna göre; sağ veya sol elin içiyle diğer elin dışına vurulması, ellerin dışının birbirine vurulması şeklinde olabileceği gibi, örfen alkış olarak ma'rûf olan, ellerin iç kısımlarının birbirine vurulması

78 Söz gelimi Reddü'l muhtâr ve Nehru'l-fầik'te kadının sesinin râcih görüşe göre avret olmadığı zikredilirken, Muhît'te aksi görüş benimsenmiştir. Bk. İbn Âbidîn, Reddü'l muhtâr, 2/79; Sirâcüddîn Ömer b. İbrâhîm b. Muhammed el-Misrî, en-Nehrü'l-fầik, nşr. Ahmed İzzû İnâye (Beyrut: Dâru'l-Kütübi'l-'İlmiyye, 1422/2002), 1/183; Burhânüddîn Mahmûd b. Ahmed b. Abdilazîz el-Buhârî, el-Muhîtüu'l-Burhân̂̂ fi'l-fikhi'n-Nu'mân̂̂ (Beyrut: Dâru'l-Kütübi'l-'İlmiyye, 1424/2004), 5/315. Kadının sesini avret olarak kabul edenlerin mevzuyu daha ziyade kadının Kur'an öğretimi sırasındaki kıraati, telbîye yapılması veya namazda tesbîh yerine el çırpması gibi örnekler üzerinden işlemeleri, kanaatimizce kadının nağmeli sesinin avret kabul edildiğini göstermektedir. Nitekim Ebü'l-Abbâs Kurtubî de konuya ilişkin şöyle der: “Zekası kıt olanlar “Kadının sesi avrettir sözümüzle kadının konuşmasını kastettiğimizi sanmasınlar. Zira bu doğru değil. Biz mahremi olmayan erkeklerin kadınlarla ihtiyaç halinde konuşmalarını tecviz ediyoruz. Ancak kadınların yüksek sesle konuşmalarını, seslerini uzatmalarını, yumuşatmalarını ve nağmeli okuyuşlarını caiz görmüyoruz. Çünkü bu durumda erkelerin meyletmeleri ve şehvetin harekete geçmesi söz konusudur. Bundan dolayı ki kadının ezan okuması da caiz değildir." Ayrıntılı bilgi için bk. İbn Âbidîn, Reddü'l muhtâr, 2/79.

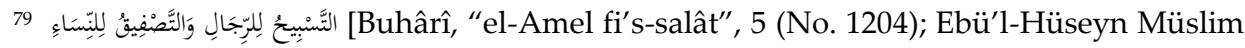
b. el-Haccâc el-Kuşeyrî, el-Câmi'u's-șahîh (Riyad: Dâru Tayyibe, 1427/2006), "Salât", 23 (No. 106, 107); Tirmizî, "Salât", 156 (No. 369)].

80 İbn Âbidîn, Reddü'l muhtâr, 2/79.

81 Ebü'l-İhlâs Hasen b. Âmmâr b. Alî eş-Şürünbülâlî, Merâkı̣'l-felâh bi-İmdâdi'l-fettâh, nşr. Ebû Abdirrahmân Salâh b. Muhammed b. 'Aveyzâ (Beyrut: Dâru'l-Kütübi'l-'İlmiyye, 1424/2004), 136-137. 
412 | F. BOZBAŞ / Namazın Rükünlerinde Kadın ve Erkeklere Yönelik Farklı Hükümler

şeklinde de yapılabilir. Bazı Şâfiîler, oyun ve eğlence manasına gelmesinden ötürü alkış şeklinde el çırpmanın uygun olmadı̆̆ını, bu hareketin hâssaten oyun amacıyla yapıldığı taktirde namazı batıl kılacağını da belirtmişlerdir. ${ }^{82}$ Bu meseleye dair Şâfiîler Ebû Hureyre ve Sehl b. Sa'd'dan nakledilen, "Sübhânallah erkekler için, el çırpma kadınlar içindir." 83 merfû hadisini delil olarak zikretmektedirler. ${ }^{84}$

2.5.3. Bu meselede Hanefî ve Şâfiîlerle aynı hükmü benimseyen Hanbelîlere göre erkekler "Sübhânallah" derken kadınlar sağ elin içiyle sol elin dışına vururlar. Bu harekette aşırıya gidilmesinin namazı bâtıl kılacağı kaydını da zikreden Hanbelîler, kadınların tesbîhle uyarıda bulunması mekrûh kabul etmişler ve bu meselede "Sübhânallah erkekler için, el çırpma kadınlar içindir." ${ }^{85}$ hadisiyle ihticâc etmişlerdir. ${ }^{86}$

Namazın rükünlerine dair hükümlerde kadın ile erkek arasında bir farklılığın bulunmadığını kabul eden Mâlikîler bu meseleye ilişkin diğer üç mezhep tarafından zikredilen hükmü reddetmişlerdir. Mâlikîler görüşlerini temellendirmede Hz. Peygamber'den (s.a.v.) namaza ilişkin zikredilen rivayetlerde bulunan âmm lafızları hareket noktası olarak kabul etmişlerdir. ${ }^{87} \mathrm{Bu}$ bağlamda namazda yanılan kimseyi uyarmak için "Sübhânallah" denilmesi hükmünün hem erkek hem de kadınlara şâmil olduğunu benimseyen Mâlikîlere göre, diğer üç sünnî mezhep tarafından delil olarak zikredilen “...El çırpma kadınlar içindir..." 88 rivâyetinde Hz. Peygamber (s.a.v.) kadınlara ilişkin farklı bir hüküm vaz' etmemekte, sadece sahabenin namaz esnasında el çırpmasını bir nev'i kadınsı bir davranış olarak zemmetmektedir. ${ }^{89}$

82 Mâverdî, Hậvi'l-kebîr, 2/163-164; Nevevî, Ravzàtü't-tạlibîn, 1/291; Râfiî, Şerhu'l-kebîr, $2 / 49$.

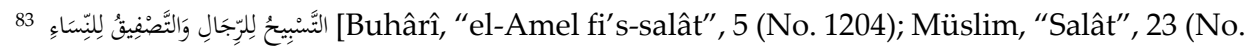
106, 107); Tirmizî, "Salât", 156 (No. 369)].

84 Mâverdî, Hậvi'l-kebîr, 2/163-164; Râfiî, Şerhu'l-kebîr, 2/49.

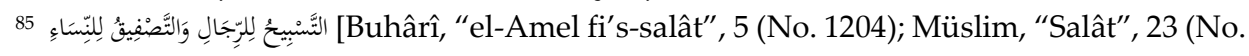
106, 107); Tirmizî, "Salât", 156 (No. 369)].

86 Buhûtî, Keşşâfu'l-ḳnâ', 1/380-381.

87 Sahnūn, Müdevvene, 1/73.

88 Rivâyetin tam metni için bk. Buhârî, "el-Amel fi's-salât", 5 (No. 1204); Müslim, "Salât", 23 (No. 106, 107); Tirmizî, “Salât”, 156 (No. 369).

89 İbn Rüşd, Bidâyetü'l-müctehid, 1/460. 


\section{Mezhep Görüşlerinin Değerlendirilmesi}

Namazın rükünlerinin niteliğine dair hükümlerde kadın ile erkek arasında farklılık olup olmadığına ilişkin sünnî fıkıh mezheplerinin iki türlü bakış açısına sahip olduğu görülmektedir.

$\mathrm{Bu}$ mevzuda en mufassal hüküm farklılıklarını benimsemiş olan Hanefîlerin görüşleri genel bir şekilde değerlendirildiğinde; fukahânın hadis kritiği açısından zayıf bazı rivâyetlerden istidlalde bulundukları, bu noktada kadının namaz içinde tesettüre riâyet etmesinin gerekliliğ i prensibinden yola çıkılarak hükümlerin rasyonel bir zemine oturtulmaya çalışıldığı intibaı uyanmaktadır. Muhtemel ki, ibadete müteallik bu mevzunun büyük ölçüde nassa dayalı ihticâca elverişli olmaması nedeniyle, Hanefîler ilgili ahkâmın vücûbiyeti veya sünnet oluşuyla ilgili kategorik bir hüküm tavsîfinde bulunmamışlardır. Halebî'nin "Kadına namazda sünnet olan şey, tesettüre en uygun hareketi yapmasıdır."90 ifadesinin ise "namazın edasına ma'tûf mezkûr hükümlerin tatbîkinin fıkhen hoş/daha münasip bir davranış olması" şeklinde yorumlanması mümkündür.

Şâfiîlerin temelde Hanefîlerle aynı doğrultuda cinsiyete göre kategorik hükümler benimsemiş olmalarına rağmen Hanefîler gibi tafsilatlı bir ayrıma gitmedikleri ve şekilsel açıdan uzun izahlarda bulunmadıkları görülmektedir. Neticede tâlî bazı hükümler dışında Şâfiî mezhebinde kadın ile erkeğin namazında neredeyse hiçbir farklılık olmadığı ortaya çıkmaktadır. Mezkûr meselelerdeki farklılıklara ilişkin, gerek İmam Şafiî̀’nin "kadın için uygun buluyorum (... أحب للمر أة (أة )" ifadesi, gerekse Şafiî fukahasının bu farklılıklara riâyet edilmemesini hoş olmayan bir davranış olarak tavsif etmekle birlikte namazın sıhhatine bir engel teşkil etmediğini beyan etmeleri, ${ }^{11}$ kanaatimizce mezkûr hükümlerin tavsiye olarak zikredildiğini, Hanefîlere kıyasla tatbîk kuvveti açısından kavî bir müstehab olarak telakki edilmediğini ortaya koymaktadır.

Mâlikîler namazın edâsına ilişkin rivayetlerdeki hitâbın âmm oluşundan hareketle hükümlerde cinsiyet temelli bir ayrım olmadığı kanaatini taşımaktadırlar.

90 İbrâhîm el-Halebî, Halebî Kebîr, 322.

91 Mâverdî, Hậvi'l-kebîr, 2/163. 
Hanbelîler ise Mâlikîlerle paralel doğrultuda prensip olarak namazın edasına ilişkin kadın ile erkek arasında bir farklılığın bulunmadığını kabul etmekle birlikte; ${ }^{92}$ Hanefî ve Şâfiîlerin de hareket noktası olan kadının tesettürüne daha ihtimam gösterebilmesi ilkesine ma'tuf farklılık arzeden bazı hükümler üzerinde durmuşlardır.

Hanbelîlerin mevzuya ilişkin görüşlerine bakıldığında; kanaatimizce zikredilen hükümlerin, sayıca oldukça az birtakım rivâyetlere istinad etse de daha ziyade aklî izahlardan beslendiği görülmektedir. İbn Teymiyye'nin, kadının namazına dair mevcut farklılıkların namazın tekâmülü için gerekli olduğunu zikretmesi, ${ }^{93}$ mezkûr ahkâmin mezhepte tavsiye niteliğinde olduğunu göstermektedir.

\section{Sonuç}

İslâm'da en önemli dinî vecibelerden biri olan namazın vücûbiyeti nasslarla belirlenirken namazın şart ve rükünlerine ilişkin hükümlerin kaynağını Hz. Peygamber'in (s.a.v.) sünneti ve sahabe uygulamaları teşkil etmiştir. Namaza ilişkin Hz. Peygamber'den (s.a.v.) nakledilen, fıkhî istidlâlin mümkün olduğu rivâyetlere bakıldığında; namazın şartlarında ve rükünlerinde kadın ile erkek arasında temelde bir farklılığın zikredilmediği, "Beni nasıl namaz kılıyor olarak gördüyseniz öylece namaz kılınız!"94 merfû hadisinin de delalet ettiği âmm hüküm gereğince namazın edâsına yönelik kadın ile erkeğin aynı hükümlere muhâtab olduğu görülmektedir.

Bununla birlikte dört fıkhî mezhebin literatürü incelendiğinde; diğer üç mezhepten farklı bir bakış açısıyla, namaza ilişkin $\mathrm{Hz}$. Peygamber'den (s.a.v.) gelen rivayetlerde âmm lafızlar bulunmasından hareketle ilgili bütün ahkâmın hem erkek hem de kadınlara şâmil olduğunu düşünen Malikîler bir yana; Hanefîler, Şâfiîler ve Hanbelîlerin, kadınların namazda iftitah tekbiri, rükû, secde, celse ve ka'dedeki hallerine ilişkin erkeklerinkinden farklı hükümler serdettikleri, görüşlerini bazı rivayetler ve aklî istidlâller ile temellendirmeye çalıştıkları görülmektedir. Bu noktada en mufassal hüküm farklılıklarına Hanefîler yer verirken, Şâfiîler ile Hanbelîler yüzeysel ölçüde ve az sayıda bazı hükümlere temas etmişlerdir.

92 İbn Kụdâme, Muginî, 2/258.

93 İbn Teymiyye, Muharrer, $1 / 67$.

صلوا كما رأيتموني أصلي [Buhârî, “Ezan”, 18 (No. 631); Beyhakī, Sünen, 2/486-487 (No. 3856)]. 
Evvelemirde; kadınlarla ilgili zikredilen hükümler umûmu'l-belva niteliği taşımakla birlikte, kendilerine fıkhî mesned teşkil eden rivayetlerin oldukça az sayıda olması kanaatimizce nazar-ı dikkate alınacak en önemli nokta olarak gözükmektedir. Hadis kritiği açısından irdelendiğinde; kadının namazda imama yanıldığını farkettirmek amacıyla "Sübhânallah" demek yerine ellerini birbirine vurması ile ilgili üç mezhep tarafından benimsenen hükmün ihticâc edildiği hadis bir yana konulacak olursa, diğer hükümlerin temelde istinâd ettiği rivayetlerin zayıf oldukları görülmektedir. Buna rağmen, içlerinde dört mezhep imamı da olmak üzere pek çok fukahânın muayyen bazı şartlar muvacehesinde zayıf hadisle amel edilebileceğini kabul etmelerinin, ilgili meselelerdeki ihticâc müşkilâtını bütünüyle olmasa da ortadan kaldırdığı düşünülebilir.

Buradan hareketle rivayetlerin sihhatine yönelik değerlendirmelerin ictihâdî olduğu, bir başka ifadeyle hadislerin sıhhatine yönelik bakış açısının muhaddis ve fukahaya göre farklılık arzettiği göz önünde bulundurulduğunda, mevzuya ilişkin istinad edilen zayıf rivayetlerin fukahâ tarafından istidlale elverişli görülmüş olması muhtemel gözükmektedir. Bu noktada fukahanın daha ziyade mana olarak değerlendirmeleri yönüyle mezkûr rivayetlere değer atfetmiş olmaları mümkün gözükmektedir. Hassaten konuya ilişkin Hanefî ve Hanbelîlerin ihticac ettiği Yezid b. Ebî Habib'ten gelen mürsel rivayete muvafık sahabe kavlinin de mevcudiyeti, teknik olarak fukahanın istidlalini kolaylaştırdığı söylenebilir. Ayrıca sahih hadis bulunmayan taabbudî konularda zayıf hadisle hüküm vermenin rey ve kıyas ile hüküm vermekten evlâ görülüyor olması ve ahkâm-ı şer'iyye haricindeki fezâil ile ilgili meselelerde zayıf hadisle amel edilebileceğine yönelik kanaatlerin de bu konuya tesir ettiği düşünülebilir.

Kadının namazındaki rükünlerin niteliğine dair serdedilen hükümlerde bazı hadis ve sahâbe kavillerine istinâd edilmesi bir yana, Şafiî literatüründe konuya ilişkin neredeyse hiçbir naklî delilin mevcut olmaması, Hanefî ve Hanbelî literatüründe ise kısmen yer bulması, kanaatimizce bu konuda üç mezhebin daha ziyade genel bazı ilkelerden hareketle hüküm verdiklerini göstermektedir. Bu noktada kadının namazına ilişkin farklılıkların mesnedine ilişkin üç mezhep literatüründe zikredilen أستر لها (kadının tesettürüne daha uygundur)" ifadesi, fukahânın 
kadınların namazına dair tesettüre uygunluk ilkesini bir ölçüt olarak ele aldıklarını göstermektedir.

Netice olarak; Beyhakî’nin de ifade ettiği gibi namazda kadınla erkek arasındaki hüküm farklılıkları tesettürle ilgili olup, bu noktada kadın, fukahâ tarafından namazda tesettürünü muhafaza etmek için en münasip şekilde hareket etmekle mükellef addedilmiştir. ${ }^{95} \mathrm{Bu}$ minvalde kanaatimizce; Hanefî, Şâfiî ve Hanbelî fukahânın taabbudî nitelikli bu mevzuda ağırlıklı olarak birtakım ilkesel ölçütlerden hareket etmeleri, ihticac edilen naklî delillerin istidlale elverişlilik açısından fezâil meselelerine münasip olması, zikredilen ahkâmin bir vücûbiyet teşkil etmediğini, fıkhen mendûb olarak telakki edilebileceğini ortaya koymaktadır.

\section{Kaynakça}

Ahmed b. Hanbel, Ebû Abdillâh Ahmed b. Muhammed b. Hanbel eşŞeybânî. Müsned. nşr. Şuayb Arnaût vd.. 5 Cilt. Beyrut: Müessesetü'r-Risâle, 1421/2001.

Beyhakī, Ebû Bekr Ahmed b. Hüseyn. es-Sünenü'l-kübrâ. thk. Muhammed Abdülkâdir Atâ. 11 Cilt. Beyrut: Dâru'l-kütübi'l-'İlmiyye, 1424/2003.

Buhârî, Ebû Abdillâh Muhammed b. İsmâil. el-Câmi'u'ṣ-șahîh. DimaşkBeyrut: Dâru İbn Kesîr, 1423/2002.

Buhûtî, Mansûr b. Yûnus b. Salâhiddîn. Keşşâfu'l-ḳnâ' 'an metni'l-İknâ'. 6 Cilt. Beyrut: 'Âlemü'l-kütüb, 1403/1983.

Burhâneddîn Buhârî, Mahmûd b. Ahmed b. Abdilazîz. el-Muhîtü'lBurhân̂̂fi'l-fikhi'n-Nu'mânî. 9 Cilt. Beyrut: Dâru'l-Kütübi'l-'Illmiyye, $1424 / 2004$.

Burhanpurlu Şeyh Nizâmüddîn vd.. el-Fetâva'l-hindiyye. 6 Cilt. Beyrut: Dâru'l-Kütübi'l-'Illmiyye, 1421/2000.

Desûkī, Ebû Abdillâh Muhammed b. Ahmed. Hâşiye 'ale'ş-Şerhị'l-kebîr. 4. Cilt. b.y.: Dâru İhyâi Kütübi'l-'Arabiyye, ts.

Ebû Dâvûd, Süleymân b. el-Eş'as es-Sicistânî. el-Merâsîl. nşr. Abdülazîz İzzüddîn es-Sirvân. Beyrut: Dâru'l-kalem, 1406/1986.

${ }^{95}$ Beyhakī, Sünen, 2/314. 
Ebû Dâvûd, Süleymân b. el-Eş'as es-Sicistânî. es-Sünen. nşr. Şuayb elArnaût vd.. 7 Cilt. Dımaşk-Hicaz: Dâru'r-Risâleti'l-'Âlemiyye, 1430/2009.

Fevzân, Sâlih b. Fevzân b. Abdillâh. Teysîru Zâde'l-Müstakni fi'l-fikhi'lHanbelî. 2 Cilt. Beyrut: Dâru'l-Kütübi'l-'İlmiyye, 1971.

Haccâvî, Ebü'n-Necâ Mûsâ b. Ahmed b. Mûsâ. İknâ' li-tâlibi'l-intifấ'. thk. Abdüllatîf Muhammed Mûsâ es-Sübkî. 4 Cilt. Beyrut: Dâru'lMa'rife, ts.

Haddâdî, Ebû Bekr b. Muhammed b. Ali. Sirâcü'l-vehhâc. Dımaşk: Dâru'lKütübi'z-Zâhiriyyeti'1-Ehliyye, 2534, 1a-522b.

Hâkim Nîsâbûrî, Ebû Abdillâh Muhammed b. Abdillâh. el-Müstedrek. thk. Mustafa Abdülkâdir Atâ. 4 Cilt. Beyrut: Dâru'l-Kütübi'l-'İlmiyye, $1422 / 2002$.

Hırakī, Ebü'l-Kāsım Ömer b. Hüseyin b. Abdillâh. Muhtasaru'l-Hırakī. thk. İbrâhîm Muhammed Ebû Huzeyfe. Tanta: Dâru's-Sahâbe, 1413/1993.

İbn Abdülber Nemerî, Ebû Ömer Yûsuf b. Abdillâh b. Muhammed.el-Kâfi fî füru'i'l-Mâlikîyye. thk. Muhammed el-Morîtânî. 2 Cilt. Riyad: Mektebetü'l-Riyâdi'l-Hadîse, 1398/1978.

İbn Âbidîn, Muhammed Emîn b. Ömer b. Abdilazîz ed-Dımaşkī. Reddü'l muhtâr 'ale'd-Dürri'l-muhtâr. thk. Âdil Ahmed Abdülmevcûd vd.. 14 Cilt. Riyâd: Dâru 'Âlemi'l-Kütüb, 1423/2003.

İbn Asker Bağdâdî, Abdurrahmân b. Muhammed b. Asker. İrşâdü's-sâlik ilâ eşrefi'l-mesâlik. Kahire: Dâru'l-Fazîle, ts.

İbn Ebî Şeybe, Ebû Bekr Abdullâh b. Muhammed b. Ebî Şeybe el-Kûfî. elMusannef. thk. Hamid b. Abdillâh el-Cum'a vd.. 16 Cilt. Riyad: Mektebetü'r-Rüşd, 1425/2004.

İbn Kudâme, Muvaffakuddîn Ebû Muhammed Abdullâh b. Ahmed elCemmâîlî. Muginî. thk. Abdullah b. Abdülmuhsin et-Türkî vd.. 15 Cilt. Riyâd: Dâru 'Âlemi'l-Kütüb, 1417/1997.

İbn Nüceym, Sirâcüddîn Ömer b. İbrâhîm b. Muhammed el-Misrî. enNehru'l-fầik. nşr. Ahmed İzzû İnâye. 3 Cilt. Beyrut: Dâru'l-Kütübi'l'İlmiyye, 1422/2002.

İbn Nüceym, Zeynüddîn b. İbrâhîm b. Muhammed el-Misrî, el-Bahrür'rrâoik. thk. Zekeriyyâ Umeyrât. 9 Cilt. Dâru'l-Kütübi'l-'Illmiyye, 1418/1997. 
418 | F. BOZBAŞ / Namazın Rükünlerinde Kadın ve Erkeklere Yönelik Farklı Hükümler

İbn Nüceym, Zeynüddîn b. İbrâhîm b. Muhammed el-Misrî. el-Eşbâh ve'nNezậir. Beyrut: Dâru'l-Kütübi'l-'Illmiyye, 1411/1991.

İbn Teymiyye, Ebü'l-Berekât Mecdüddîn Abdüsselâm b Abdillâh elHarrânî. el-Muharrer fi'l-fikh 'alâ mezhebi'l-İmâm Ahmed b. Hanbel. 2 Cilt. Beyrut: Dâru'l-Kitâbi'1-'Arabî, 1378/1959.

İbnü'l-Hümâm, Kemâlüddîn Muhammed b. Abdilvâhid es-Sivâsî. Fethu'l-kadîr li'l-'âcizi'l-fakìr. thk. Abdurrâzik Gâlib el-Mehdî. 10 Cilt. Beyrut: Dâru'l-Kütübi'l-'İlmiyye, 1424/2003.

İbnü's-Sââtî, Ebü'l-Abbâs Muzafferüddîn Ahmed b. Alî el-Bağdâdî. Mecma'u'l-bahreyn ve mülteka'n-neyyireyn. thk. İlyas Kaplan. Beyrut: Dâru'l-Kütübi'l-'İlmiyye, 1426/2005.

İmam Şâfiî, Ebû Abdillâh Muhammed b. İdris. el-Ümm. thk. Rıfat Fevzî Abdülmuttalib. 11 Cilt. Kahire: Dâru'l-Vefâ, 1422/2000.

Halebî, İbrâhîm b. Muhammed. Gunyetü'l-mütemellî fí șerhi Münyeti'lMusallî: Halebî Kebîr. b.y.: Dâru Saâde, 1325.

Kâsânî, Alâüddîn Ebû Bekr b. Mes'ûd b. Ahmed. Bedâ'i' $i^{\prime} u^{\prime} s$-ṣanâ'i' fî tertîbi'ş-şerâ'i'. thk. Ali Muhammed Muavvız vd.. 10 Cilt. Beyrut: Dâru'l-Kütübi'l-'İlmiyye, 1424/2003.

Kurtubî, Ebü'l-Velîd Muhammed b. Ahmed. Bidâyetüll-müctehid ve nihâyetü'l-mukteșid. thk. Muhammed Subhî Hasen Hallâk. 4 Cilt. Kahire: Mektebetü İbn Teymiyye, 1415/1995.

Mâverdî, Ebü'l-Hasen Alî b. Muhammed. el-Hâavi'l-kebîr. thk. Alî Muhammed Muavvız vd.. 18 Cilt. Beyrut: Dâru'l-Kütübi'l-'İlmiyye, 1414/1994.

Mergīnânî, Ebü'l-Hasen Burhânüddîn Alî b. Ebî Bekr b. Abdilcelîl. elHidâye. thk. Nuaym Eşref Nûr Muhammed. 8 Cilt. Karaçi: İdâretü'1Kur'ân ve'l-‘Ulûmi'l-İslâmiyye, 1417/1997.

Mevsılî, Ebü'l-Fazl Mecdüddîn Abdullah b. Mahmûd. el-i̇htiyâr li-tâ'lîli'lMuhtâr. thk. Hâlid Abdurrahman el-Ak. 4 Cilt. Beyrut: Dâru'lMa'rife, 1423/2002.

Molla Hüsrev. Dürerü'l-hükkâm fî şerhi Gureri'l-ahkâm. 2 Cilt. Karaçi: Mîr Muhammed Kütüphâne, ts.

Munawwar, Munir Ahmad. Mard Wa Aurat Ki Namaz Ke Farg Par Tafsili Jazia. b.y.: Mektebetü Ehlü's-Sünne ve'l-Cemaat, ts. 
Müslim, Ebü'l-Hüseyn Müslim b. el-Haccâc el-Kuşeyrî. el-Câmi'u's-ṣahîh. thk. Nazar b. Muhammed el-Faryâbî. 2 Cilt. Riyad: Dâru Tayyibe, $1427 / 2006$.

Müzenî, Ebû İbrâhîm İsmâîl b. Yahyâ. el-Mecmû' Şerhu'l-Mühezzzeb. thk. Muhammed Necîb el-Muti'î. 23 Cilt. Cidde: Mektebetü'l-İrşâd, ts.

Nevevî, Ebû Zekeriyyâ Yahyâ b. Şeref. Ravzatü't-tâlibîn. thk. Züheyr eşŞâviş. 12 Cilt. Beyrut: el-Mektebü'l-İslâmî, 1412/1991.

Râfiî, Ebü'l-Kāsım Abdülkerîm b. Muhammed. el-Fethu'l-'azîz fì Şerhị'lVecîz (eş-Şerhu'l-kebîr). thk. Alî Muhammed Muavvız vd.. 13 Cilt. Beyrut: Dâru'1-Kütübi'l-'İlmiyye, 1417/1997.

Sạhnūn, Ebû Saîd Abdüsselâm b. Saîd et-Tenûhî. el-Müdevvenetü'l-kübra'. 16 Cilt. b.y.: Vizâretü'l-Evkâfi's-Suûdiyye, 1324/1906.

Serahsî, Ebû Bekr Muhammed b. Ebî Sehl. el-Mebsût. 31 Cilt. Beyrut: Dâru'l-Ma'rife, 1409/1989.

Şürünbülâlî, Ebü'l-İhlâs Hasen b. Âmmâr b. Alî. Merâkı'l-felâh bi-İmdâdi'lfettâh. nşr. Ebû Abdirrahmân Salâh b. Muhammed b. 'Aveyzâ. Beyrut: Dâru'l-Kütübi'l-'İlmiyye, 1424/2004.

Tirmizî, Ebû Îsâ Muhammed b. Îsâ. el-Câmi'u's-sahîh. nşr. Beşşâr Avvâd Ma'rûf. 6 Cilt. Beyrut: Dâru'1-Garbi'l-İslâmî, 1996.

Zeylaî, Abdullah b. Yûsuf. Naṣbü'r-râye li-ehâdîsíl'l-Hidâye. 5 Cilt. Cidde: Dâru'l-Kible li-Sekâfeti'l-İslâmiyye, ts.

Zeylaî, Ebû Muhammed Osman b. Ali b. Mihcen. Tebyînü'l-hakā̄ik. 6 Cilt. Multan: Mektebetü İmdâdiyye, ts.

Zuhaylî, Vehbe. el-Fıkhu'l-İslâmî ve edilletuh. 4 Cilt. Dımaşk: Dâru'l-fikr, 1405/1985. 